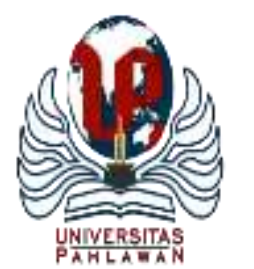

Edukatif : Jurnal Ilmu Pendidikan Volume 4 Nomor 1 Tahun 2022 Halm 399 - 410 EDUKATIF: JURNAL ILMU PENDIDIKAN

Research \& Learning in Education

https:/ledukatif.org/index.php/edukatif/index

\title{
Pengaruh Pendidikan Karakter Mandiri dan Jujur Terhadap Hasil Belajar Ekonomi Koperasi Saat Pandemi Covid-19
}

\author{
Putri Sugiyanti $^{1 凶}$, Ni’matush Sholikhah $^{2}$ \\ Universitas Negeri Surabaya, Indonesia ${ }^{1,2}$ \\ E-mail : putri.17080554022@mhs.unesa.ac.id ${ }^{1}$, nimatushsholikhah@unesa.ac.id ${ }^{2}$
}

\begin{abstract}
Abstrak
Proses pembelajaran yang dilaksanakan di Madrasah Aliyah Negeri 2 Gresik selama masa pandemi dilakukan secara daring karena pandemi Covid-19, dengan memakai teknologi dan implementasi yang mempermudah pembelajaran siswa seperti WhatsApp, Goggle Meet, Zoom dan aplikasi lainnya yang mendukung siswa saat pembelajaran jarak jauh (Daring). Pendidikan karakter yang diterapkan sebelum pandemi di Madrasah Aliyah Negeri 2 Gresik yaitu pembiasaan siswa seperti upacara bendera setiap hari Senin, sholat Dhuha saat istirahat, sholat dhuhur berjamaah, menjalankan sholat Jum'at bagi siswa laki-laki, dan untuk siswi ada kegiatan keputrian selama sholat Jum'at dilaksanakan, dan Ubudiya. Penelitian bertujuan untuk menganalisis keterkaitan pendidikan karakter mandiri dan pendidikan karakter jujur pada hasil belajar ekonomi. Sampel diambil melalui siswa Kelas X di Madrasah Aliyah Negeri 2 Gresik berjumlah 102 responden. Metode dari pengambilan data memakai eksplorasi, studi kepustakaan serta kuisioner secara online. Instrumen penelitian menerapkan skala ukur likert. Hasil penelitian menyatakan bahwa secara parsial tidak ada keterkaitan antar pendidikan karakter mandiri pada hasil belajar ekonomi, secara parsial ada pengaruh positif serta signifikan antara pendidikan karakter jujur terhadap hasil belajar ekonomi, secara simultan ada hubungan signifikan antara pendidikan karakter mandiri dan karakter jujur terhadap hasil belajar ekonomi.
\end{abstract}

Kata Kunci: Pendidikan Karakter Mandiri, Pendidikan Karakter Jujur, Hasil Belajar

\begin{abstract}
Learning process carried out at Madrasah Aliyah Negeri 2 Gresik during pandemic was carried out online due to covid19 pandemic, using technology and implementations that facilitate student learning such as WhatsApp, Goggle Meet, Zoom and other applications support students during distance learning (Online). Character education that was implemented before pandemic at Madrasah Aliyah Negeri 2 Gresik was habituation of students such as the flag ceremony every Monday, Duha prayer during breaks, dhuhur prayers in congregation, Friday prayers for male students, and for female students there were women's activities during prayer. Friday held, and Ubudiya. This study aims to analyze relationship between independent character education and honest character education on economic learning outcomes. Sample was taken through the students of Class X at Madrasah Aliyah Negeri 2 Gresik totaling 102 respondents. Methods of data collection using exploration, literature study and online questionnaires. The research instrument applies a Likert scale. The results of study state that partially there is no relationship between independent character education on economic learning outcomes, partially there is a positive and significant influence between honest character education on economic learning outcomes, simultaneously there is a significant relationship between independent character education and honest character on economic learning outcomes.
\end{abstract}

Keywords: Independent Character Education, Honest Character Education, Learning Outcomes

Copyright (c) 2022 Putri Sugiyanti, Ni'matush Sholikhah

$\triangle$ Corresponding author

Email : putri.17080554022@mhs.unesa.ac.id

DOI : https://doi.org/10.31004/edukatif.v4i1.1755

ISSN 2656-8063 (Media Cetak)

ISSN 2656-8071 (Media Online)

Edukatif : Jurnal Ilmu Pendidikan Vol 4 No 1 Tahun 2022 p-ISSN 2656-8063 e-ISSN 2656-8071 


\section{PENDAHULUAN}

Pendidikan ialah usaha yang sedang dilalui oleh manusia untuk mendapatkan pelajaran yang nantinya dibuat sebagai pedoman dalam bertindak dan berperilaku Marzuki (2015). Pendidikan merupakan suatu proses pembentukan karakter siswa, semua proses yang dilakukan oleh manusia akan menghasilkan sikap dan perilaku yang pada dasarnya akan membentuk kepribadian atau karakter siswa. Pendidikan dalam jangka waktu yang panjang bisa membuat manusia berhasil, dan berkarakter maka akan membuat manusia yang pantas dan layak untuk dihargai dilingkungan masyarakat. untuk bisa mewujudkan manusia yang maju dan berkualitas serta mampu berdaya saing dengan orang asing. Usaha yang dilakukan masyarakat dan bangsa dalam pendidikan yaitu menyiapkan generasi muda guna mewujudkan masa depan negara yang baik.

Pemerintah dalam Menteri Pendidikan dan Kebudayaan, Nadiem Makarim mengumumkan dengan surat edaran pada Nomor 36962/MPK.A/HK/2020 yang memutuskan untuk membedakan pembelajaran offline menjadi pembelajaran secara (Daring). Dalam pembelajaran dengan jarak jauh (Daring), peserta didik dan guru diwajibkan untuk memiliki android yang terhubung dengan koneksi internet karena semua informasi pembelajaran pada saat ini hanya bisa diakses melalui internet. Pembelajaran yang dilakukan tatap muka maupun pembelajaran dengan jarak jauh (Daring) harus melibatkan 3 aktivitas utama yang saling berkaitan yaitu (1) kegiatan presentasi yakni pemaparan atau penyajian materi pembelajaran (2) kegiatan interaksi yakni aktivitas komunikasi timbal balik yang dilakukan oleh pelajar dengan guru (fasilitator) dan (3) kegiatan evaluasi yakni kegiatan yang dilaksanakan agar mengetahui kemajuan dan ketercapaian rencana belajar yang telah dilakukan (Wibawanto, 2017). Dengan guru masih menerapkan aktivitas pada pembelajaran jarak jauh guru masih bisa menguasai pemahaman peserta didik dengan mendesain atau merubah model pembelajaran yaitu dengan memanfaatkan teknologi agar siswa masih bisa meningkatkan hasil belajar meskipun tidak secara langsung.

Pendidikan karakter merupakan program kegiatan pembelajaran di sekolah yang mempunyai tujuan untuk mengelola perkembangan sifat dan perilaku siswa dengan usaha mengamalkan nilai serta keyakinan masyarakat sebagai kemampuan moral dalam hidup dengan berbuat jujur, dapat diandalkan, tepat waktu, mandiri, dan kerja sama yang mengacu pada ranah secara afektif (perasaan/sikap) tidak mengabaikan ranah kognitif (berfikir rasional) serta ranah skill (keterampilan/ kemampuan) (Zubaedi, 2011). Pendidikan karakter merupakan suatu rencana pembelajaran yang membuat peserta didik serta orang dewasa pada organisasi sekolah agar menerapkan rasa peduli tentang dan berbuat berlandaskan nilai-nilai etik misal simpati, keadilan, kebijakan warga (civic virtue), kewarganegaraan (cittienship) dan bertanggung jawab atas diri sendiri ataupun kepada orang lain (Samani \& Hariyanto, 2011). Kondisi pandemi Covid-19 membuat sanggahan untuk dunia pendidikan khususnya pendidikan formal saat usaha mewujudkan pendidikan karakter bangsa. Pembelajaran dominan tidak hanya dilaksanakan dengan saling bertemu, sehingga menjadi tantangan bagi guru ketika penerapan pendidikan karakter. Disisi lain membagikan peluang bagi peserta didik dalam mengimplementasikan nilai karakter pada masyarakat ketika upaya pecegahan maupun penanggulangan Covid19.

Proses pembelajaran yang dilaksanakan di Madrasah Aliyah Negeri 2 Gresik selama masa pandemi ini dijumpai secara daring sebab pandemi Covid-19, dengan memakai teknologi dan aplikasi yang mempermudah pembelajaran siswa seperti WhatsApp, Goggle Meet, Zoom dan aplikasi lainnya yang mendukung siswa saat pembelajaran jarak jauh (Daring). Pendidikan karakter yang diterapkan sebelum pandemi di Madrasah Aliyah Negeri 2 Gresik yaitu pembiasaan siswa seperti upacara bendera setiap hari Senin, sholat Dhuha saat istirahat, sholat dhuhur berjamaah, melakukan sholat Jum'at bagi siswa laki-laki, dan untuk siswi ada kegiatan Keputrian selama sholat Jum'at dilaksanakan, dan Ubudiya. Sedangkan pada saat kondisi pandemi pendidikan karakter yang diterapkan disekolah sedikit berbeda dengan kondisi normal pada umumnya, karena guru hanya bisa 
401 Pengaruh Pendidikan Karakter Mandiri dan Jujur Terhadap Hasil Belajar Ekonomi Koperasi Saat Pandemi Covid-19 - Putri Sugiyanti, Ni'matush Sholikhah

DOI: https://doi.org/10.31004/edukatif.v4i1.1755

memantau kegiatan siswa melalui tugas yang dikirim siswa melalui WhatsApp sebab guru tidak bisa memantau siswa secara langsung.

Pengembangan karakter siswa di Madrasah Aliyah Negeri 2 Gresik sangat baik, hal tersebut terbukti ketika siswa menerapkan pendidikan karakter mandiri dan jujur yang sudah diterapkan disekolah . Pendidikan karakter tersebut tidak hanya diterapkan oleh peserta didik melainkan kepada semua guru bidang studi juga ikut serta menerapkan pembentukan pendidikan karakter mandiri dan jujur. Pembentukan pendidikan karakter juga diberikan selama mata pelajaran, pendidikan karakter mandiri yaitu meliputi mengerjakan serta mengumpulkan tugas dengan tepat waktu, serta melakukan belajar mandiri agar dapat memahami materi dengan baik, selanjutnya pembentukan karakter jujur yang dilakukan peserta didik saat pembelajaran yaitu tidak menjiplak saat mengerjakan ujian, dan melaksanakan tugas atau ujian tidak memberi jawaban atau memberi jawaban kepada peserta didik yang lain.

Menurut Waliyanti (2014) pembentukan karakter mandiri tidak hanya diberikan melalui teori atau saat pembelajaran saja akan tetapi pembentukan karakter mandiri diberikan melalui kegiatan-kegiatan yang melibatkan praktik kegiatan sehari-sehari peserta didik, yang ada pada lingkungan sekolah maupun pada lingkungan di masyarakat. Bahwa untuk membentuk pendidikan karakter mandiri dilakukan melalui tanggung jawab, disiplin, kemampuan hidup yang dilakukan secara rutin yang dapat membangun karakter mandiri pada peserta didik.

Menurut Puspita (2012) kejujuran dalam pendidikan karakter disekolah memiliki peran penting untuk membentuk karakter peserta didik pada era ini guna sebagai pedoman pada kehidupan dimasa yang akan datang, karakter jujur bisa dilihat secara langsung dalam kelas atau saat pandemi hanya bisa melalui WhatsApp grup pada proses pembelajaran maupun saat menuntaskan ujian, perbuatan mencontek/meniru jawaban teman merupakan perilaku yang menandakan bahwa peserta didik tidak jujur kepada diri sendiri, teman, orang tua dan juga kepada guru. Pembentukan karaker jujur yang diterapkan disekolah meliputi beberapa indikator yaitu (1) tidak memberi jawaban atau menyalin jawaban teman yang dekat atau teman sekelas, (2) berkata jujur mengatakan dengan sejujur-jujurnya tentang sesuatu yang sedang terjadi, (3) bercerita apapun yang terjadi dan mau bercerita dengan teman akrab dan siap menerima pendapat yang telah diberikan oleh teman, (4) menjawab pertanyaan yang diberikan guru berdasarkan apa yang sudah diketahui oleh peserta didik selama pembelajaran (Puspita, 2012). Kejujuran dapat membawa dampak positif pada kehidupan peserta didik, dan juga mengembangkan kehidupan yang lebih baik dari sebelumnya, tanpa kejujuran kondisi kehidupan peserta didik pasti terganggu dan memiliki dampak negatif bagi kehidupan peserta didik kedepanya, atau mengalami kemunduran dari segala upaya yang sedang dilakukan (Yaumi, 2014).

Salah satu kriteria keberhasilan dalam penerapan pendidikan karakter adalah hasil belajar peserta didik didalam lingkungan pendidik akan memiliki dampak langsung pada hasil belajar, (Rostrieningsih \& Maisaroh, 2010). Menurut Sudjana (2010) hasil belajar adalah potensi yang dimiliki siswa sesudah menerima pengalaman belajarnya. Diharapkan pendidikan karaker mandiri dan jujur pesera didik Madrasah Aliyah Negeri 2 Gresik, mampu secara mandiri untuk meningkatkan pengetahuan yang didapatkan agar hasil belajar dapat memenuhi Kriteria Ketuntasan Minimun (KKM) dalam mata pelajaran terutama di mata pelajaran ekonomi materi koperasi pada kelas X IPS. Hasil belajar yang dipakai yakni nilai Ulangan Harian dan juga tugas KD 3.8 yaitu mendeskripsikan perkoperasian dalam perekonomian Indonesia dan 4.8 mengimplementasikan pengelolaan koperasi di sekolah materi koperasi.

Berdasarkan penelitian terdahulu, (Jannah, 2018) menunjukkan bahwa pengaruh pembelajaran berbasis pendidikan karakter terhadap hasil belajar siswa di MTs N 9 Sleman, mendapat hasil penelitian yang mengungkapkan bahwa terdapat pengaruh yang signifikan antara pembelajaran dengan penerapan pendidikan karakter pada hasil belajar. Penelitian serupa juga dilakukan oleh (Wahyuliono, 2013) menunjukkan pendidikan karakter disiplin serta pendidikan karakter mandiri berhubungan signifikan pada hasil pembelajaran peserta didik kelas XI TPM di SMKN 1 Trenggalek, hasil penelitian mengungkapkan secara bersamaan pendidikan 
402 Pengaruh Pendidikan Karakter Mandiri dan Jujur Terhadap Hasil Belajar Ekonomi Koperasi Saat Pandemi Covid-19 - Putri Sugiyanti, Ni'matush Sholikhah

DOI: https://doi.org/10.31004/edukatif.v4i1.1755

karakter disiplin dan pendidikan karakter mandiri berperan dalam upaya peningkatan hasil belajar siswa. State of the art pada penelitian ini terdapat beberapa perbedaan. Pada penelitian ini subjek penelitiannya berfokus kepada peserta didik Madrasah Aliyah Negeri yang memiliki pendidikan karakter lebih pada penanaman nilainilai agama di sekolah. Selain itu, penelitian ini dilaksanakan pada kondisi pandemi Covid-19, dengan menggunakan media pembelajaran berbasis digital.

Dari beberapa penjelasan tentang permasalahan yang terjadi disekolah terutama di kelas X IPS mata pelajaran ekonomi materi koperasi, untuk dapat mencari solusi atas masalah tersebut peneliti melaksanakan sebuah penelitian yang berjudul "Pengaruh Pembentukan Karakter Mandiri Dan Jujur Terhadap Hasil Belajar Ekonomi Koperasi Pada Saat Pandemi Covid-19" harapannya setelah peneliti melakukan penelitian terhadap sekolah tersebut dapat mengatasi masalah tentang pembelajaran ekonomi materi koperasi melalui pendidikan karakter mandiri dan jujur dikelas dengan sebaik-baiknya.

\section{METODE PENELITIAN}

Jenis penelitian yaitu kuantitatif dengan menerapkan pendekatan deskriptif. Menurut penelitian kuantitatif adalah Penelitian kuantitatif ialah penelitian yang menggunakan asumsi-asumsi. (Priyono, 2008). Analisis kuantitatif memakai data berupa angka hasil perhitungan dan pengukuran yang diolah serta dianalisis menggunakan kriteria statistika tertentu.

Sumber data dipakai dalam penelitian ini yakni data primer dan data sekunder. Data primer adalah data berwal dari sumber asli atau pertama, (Pratiwi, 2017). Sumber data primer dalam penelitian didapatkan dari data kuisioner yang diisi oleh siswa. Data sekunder merupakan data yang didapatkan atas metode membaca, mempelajari dan memahami melalui media lain yang bersumber dari literatur, buku-buku, dan dokumen sumber data yang dihasilkan dari berbagai sumber seperti jurnal, internet, dsb. (Sugiyono, 2019). Selain itu, juga termasuk data nilai hasil belajar siswa.

Populasi penelitian ini adalah siswa kelas X IPS 1,2,3, dan 4 MAN 2 Gresik sebanyak 137 siswa.

Tabel 1 Jumlah Responden

\begin{tabular}{cc}
\hline Kelas & Jumlah Siswa \\
\hline X IPS 1 & 34 \\
\hline X IPS 2 & 34 \\
\hline X IPS 3 & 35 \\
\hline X IPS 4 & 34 \\
\hline
\end{tabular}

Teknik pengambilan sampel dalam studi ini yaitu dengan metode sampling Probability Sampling berjenis Simple Random Sampling. Versi untuk memastikan ukuran sampel memakai Degree of Variability melalui finit/populasi diketahui. Teknik simple random sampling dihitung dengan rumus sebagai berikut:

$$
n=\frac{\mathrm{N}}{1+\mathrm{n}(\mathrm{e})^{2}}
$$

Sumber : (Sugiyono, 2019)

Perhitungan sampel mendapat hasil sebagai berikut:

$$
n=\frac{137}{1+135(0,05)^{2}}=\frac{137}{1,3425}=102 \text { siswa }
$$

Dengan demikian, ditarik kesimpulan yakni sampel penelitian ini diambil sejumlah 102 siswa dengan teknik sampling Probability Sampling jenis simple random sampling. 
Teknik analisis data yang diterapkan yakni statistik deskriptif. Data penelitian dianalisis dengan teknik regresi linear sederhana melalui software SPSS 16. Metode akumulasi data dengan observasi, studi pustaka serta kuesioner. Studi ini menggunakan skala likert. Untuk analisis kuantitatif, memiliki 5 jawaban yang diperlukan antara lain: SS (sangat setuju), S (setuju), KK (kadang-kadang), HTP (hampir tidak pernah), TP (tidak pernah) dengan mendapat nilai skor dari tiap jawabannya, (Sugiyono, 2012). Dalam penelitian ini memiliki 5 indikator pada variabel pendidikan karakter mandiri diantaranya yaitu melaksanakan perintah dengan semestinya ketika aktivitas pembelajaran secara langsung, fokus, dan serius, serta bisa koheren saat kegiatan pembelajaran berlangsung, mempunyai rasa percaya diri atau yakin dapat menuntaskan tugas yang diterima, memperlihatkan kapasitas belajar mandiri sinkron pada bakat yang ada pada dirinya, menuntaskan sendiri kewajiban serta tangunggan yang diberikan dengan tidak menjiplak hasil jawaban teman yang lainnya. (Chairil Faif Pasani \& Mitra Pramita, 2014). Selain itu, pada variabel pendidikan karakter jujur mempunyai 5 indikator diantaranya yaitu tidak menjiplak ketika melaksanakan ujian, tidak menjadi plagiat (mengambil/menyalin karya orang lain tanpa memperlihatkan sumber), membagikan kepada yang berwajib barang yang ditemukan, membuat laporan berdasakan data atau fakta adanya, mengakui kesalahan atau kekurangan yang dipunyai. (Permendikbud, 2013). Pada variabel hasil belajar memiliki satu indikator yaitu nilai ulangan harian siswa mata pelajaran ekonomi bab koperasi (Purwanto, 2012).

Analisis data yang dipakai yaitu statistik deskriptif. Tahapan dapat terwujud diantaranya instrumen penelitian sebagai syarat uji validitas dan reliabilitas, pengambilan data dengan menyebar kuisioner kepada siswa, selanjutnya proses tabulasi data, perbedaan data skala ordinal menjadi data interval memakai metode Suksesif Interval (MSI). Dalam metode statistik seperti regresi linier, mewajibkan data dengan skala interval. Oleh karena itu, apabila memiliki data berskala ordinal maka data harus diubah dalam bentuk skla interval guna memenuhi persyaratan prosedur tersebut. Tahapan selanjutnya, peneliti melakukan uji asumsi klasik dan uji hipotesis. Uji asumsi klasik penelitian meliputi uji normalitas, uji linearitas, uji multikolineritas dan uji heteroskedastisitas. Selain itu, peneliti juga melakukan uji hipotesis dengan koefisien determinasi/R-Square, dan uji f, serta uji t.

\section{HASIL DAN PEMBAHASAN PENELITIAN}

Data yang didapatkan guna menganalisa keterkaitan variabel pendidikan karakter mandiri dan karakter jujur pada hasil belajar siswa. Data diambil oleh kuisioner online dengan 102 responden dari siswa MAN 2 Gresik Kelas XI IPS 1-4. Kuisioner menggunakan skala pengukuran likert atas rentang skor 1-5. Studi ini memakai 2 variabel bebas bersama 11 indikator. Variabel satu yakni pendidikan karakter mandiri dengan 5 indikator peryataan dan jumlah pertanyaan sebanyak 8. Variabel kedua yaitu pendidikan karakter jujur dengan 5 indikator pertanyaan dengan jumlah pertanyaan sebanyak 5. Dengan demikian, total pertanyaan 10 . Responden mengisi kuisioner penelitian ini mempunyai karakteristik pendidikan karakter mandiri dan jujur dari sekolah.

Variabel penelitian terdiri atas dua variabel independent yaitu variabel pendidikan karakter mandiri dan karakter jujur dan terdiri satu variabel dependent yaitu hasil belajar. Berdasarkan hasil penyebaran angket yang dipaparkan dalam penelitian ini yakni guna memberi pengetahuan umum tentang proses penyebaran data yang diperoleh di lapangan mengenai variabel pendidikan karakter mandiri, pendidikan karakter jujur, dan hasil belajar. Data yang disajikan sudah merupakan skor total dari masing-masing sub indikator variabel pendidikan karakter mandiri dan pendidikan karakter jujur. Data diambil dari 102 responden secara acak dari keempat kelas yaitu kelas X IPS 1, X IPS 2, X IPS 3, X IPS 4. Proses validitas, butir pernyataan diakui valid dengan taksir signifikansi $<0.05$. Rata-rata jawaban responden bernilai 3, yang artinya responden kurang dalam melaksanakan aktivitas di sekolah yang dapat membentuk karakter mandiri serta jujur. Oleh karena itu, diperlukan penerapan kebiasaan pendidikan karakter disekolah dengan waktu yang lebih banyak dengan 
kondisi yang mendukung pembelajaran daring. Pada indikator pendidikan karakter mandiri dengan jumlah 8 pertanyaan juga mendapatkan taksir rata-rata sebesar \pm 3 bahwa peserta didik menjawab cukup setuju. Pada indikator pendidikan karakter jujur dengan total pertanyaan 4 mendapatkan rata-rata sebesar \pm 4 artinya yakni peserta didik cukup sering melaksanakan kegiatan-kegiatan yang jujur di sekolah. Dalam penelitian ini memiliki 5 indikator dan 11 pertanyaan pada variabel pendidikan karakter mandiri diantaranya yaitu melakukan perintah dengan sewajarnya saat kegiatan dikelas berlangsung, fokus, dan serius, serta koheren saat aktivitas pembelajaran sedang berlangsung, mempunyai rasa percaya diri atau keyakinan ketika menuntaskan tugas yang menjadi tanggungjawabnya, memperlihatkan kemampuan belajar secara mandiri sesuai dengan potensi yang ada pada diri, mengerjakan/menyelesaikan sendiri tugas serta latihan yang diberikan dengan tidak mencontek/meniru jawaban teman yang lain. (Chairil Faif Pasani \& Mitra Pramita, 2014). Dalam hasil uji validitas tersebut, beberapa pertanyaan yang tidak valid tidak dilanjutkan pada proses olah data. Berikut tabel hasil uji validitas yang telah dilakukan peneliti:

\section{a.) Hasil Uji Validitas Variabel Pendidikan Karakter Mandiri}

Tabel 2 Hasil Uji Validitas Variabel Pendidikan Karakter Mandiri

\begin{tabular}{|c|c|c|c|c|}
\hline No & Indikator & & Item Kuisioner & $\begin{array}{l}\text { Hasil Uji } \\
\text { Validitas }\end{array}$ \\
\hline \multirow[t]{2}{*}{1.} & \multirow[t]{2}{*}{$\begin{array}{l}\text { Melakukan perintah } \\
\text { dengan sebaik- } \\
\text { baiknya saat kegiatan } \\
\text { pembelajaran } \\
\text { berlangsung }\end{array}$} & 1) & $\begin{array}{l}\text { Saya mematuhi } \\
\text { instruksi dengan baik } \\
\text { selama proses } \\
\text { pembelajaran } \\
\text { berlangsung. }\end{array}$ & Valid \\
\hline & & 2) & $\begin{array}{l}\text { Saya menjalankan } \\
\text { instruksi dengan baik } \\
\text { selama proses } \\
\text { pembelajaran } \\
\text { berlangsung. }\end{array}$ & Valid \\
\hline \multirow[t]{3}{*}{2.} & \multirow{3}{*}{$\begin{array}{l}\text { Fokus, serius, dan } \\
\text { dapat konsisten } \\
\text { selama proses } \\
\text { pembelajaran } \\
\text { berlangsung }\end{array}$} & 3) & $\begin{array}{l}\text { Saya fokus ketika } \\
\text { pembelajaran } \\
\text { berlangsung. }\end{array}$ & Valid \\
\hline & & 4) & $\begin{array}{l}\text { Saya serius ketika } \\
\text { pembelajaran } \\
\text { berlangsung. }\end{array}$ & Valid \\
\hline & & 5) & $\begin{array}{l}\text { Saya dapat konsisten } \\
\text { ketika proses } \\
\text { pembelajaran } \\
\text { berlangsung. }\end{array}$ & Valid \\
\hline
\end{tabular}

3. Memiliki

kepercayaan diri atau keyakinan dalam menyelesaikan tugas yang diberikan
6) Saya percaya diri Valid saat menyelesaikan tugas yang diberikan guru.

7) Saya yakin dapat Valid menyelesaikan tugas yang diberikan guru. 
405 Pengaruh Pendidikan Karakter Mandiri dan Jujur Terhadap Hasil Belajar Ekonomi Koperasi Saat Pandemi Covid-19 - Putri Sugiyanti, Ni'matush Sholikhah

DOI: https://doi.org/10.31004/edukatif.v4i1.1755

\begin{tabular}{|c|c|c|c|}
\hline No & Indikator & Item Kuisioner & $\begin{array}{l}\text { Hasil Uji } \\
\text { Validitas }\end{array}$ \\
\hline \multirow[t]{2}{*}{4} & $\begin{array}{l}\text { Menunjukkan } \\
\text { kemampuan belajar } \\
\text { secara mandiri sesuai } \\
\text { dengan potensi yang } \\
\text { ada pada dirinya }\end{array}$ & $\begin{array}{l}\text { 8) Ketika belajar, saya } \\
\text { lakukukan dengan } \\
\text { mandiri tanpa } \\
\text { bantuan dari orang } \\
\text { lain. }\end{array}$ & Valid \\
\hline & & 9) $\begin{array}{l}\text { Saya merupakan } \\
\text { orang yang senang } \\
\text { bersosialisasi dan } \\
\text { mudah beradaptasi. }\end{array}$ & Tidak Valid \\
\hline \multirow[t]{2}{*}{5.} & $\begin{array}{l}\text { Mengerjakan/menyel } \\
\text { esaikan sendiri tugas } \\
\text { dan latihan yang } \\
\text { diberikan dengan } \\
\text { tidak }\end{array}$ & $\begin{array}{l}\text { 10) Saya dapat } \\
\text { menyelesaikan } \\
\text { sendiri tugas dan } \\
\text { latihan yang } \\
\text { diberikan guru. }\end{array}$ & Valid \\
\hline & $\begin{array}{l}\text { mencontek/meniru } \\
\text { pekerjaan teman } \\
\text { yang lain }\end{array}$ & $\begin{array}{l}\text { 11) Saya tidak pernah } \\
\text { mencontek/meniru } \\
\text { pekerjaan teman. }\end{array}$ & Valid \\
\hline
\end{tabular}

\section{b.) Hasil Uji Validitas Variabel Pendidikan Karakter Jujur}

Tabel 3 Hasil Uji Validitas Pendidikan Karakter Jujur

\begin{tabular}{|c|c|c|c|c|}
\hline No & Indikator & & Item Kuisioner & $\begin{array}{l}\text { Hasil Uji } \\
\text { Validitas }\end{array}$ \\
\hline \multirow[t]{2}{*}{1} & $\begin{array}{l}\text { Tidak menyontek dalam } \\
\text { mengerjakan ujian/ulangan }\end{array}$ & 1) & $\begin{array}{l}\text { Saya tidak pernah } \\
\text { menyontek ketika } \\
\text { mengerjakan } \\
\text { ujian/ulangan. }\end{array}$ & Valid \\
\hline & & 2) & $\begin{array}{l}\text { Saya selalu jujur ketika } \\
\text { mengerjakan } \\
\text { ujian/ulangan. }\end{array}$ & Valid \\
\hline \multirow[t]{2}{*}{2.} & $\begin{array}{l}\text { Tidak menjadi plagiat } \\
\text { (mengambil/menyalin karya } \\
\text { orang lain tanpa } \\
\text { menyebutkan sumber) }\end{array}$ & 3) & $\begin{array}{l}\text { Saya tidak pernah } \\
\text { menjadi plagiat } \\
\text { (mengambil/menyalin } \\
\text { karya orang lain tanpa } \\
\text { menyebutkan sumber). }\end{array}$ & Valid \\
\hline & & 4) & $\begin{array}{l}\text { Saya selalu } \\
\text { mencantumkan dumber } \\
\text { referensi ketika } \\
\text { mengutip karya orang } \\
\text { lain. }\end{array}$ & Valid \\
\hline & $\begin{array}{l}\text { Menyerahkan kepada yang } \\
\text { berwenang barang yang } \\
\text { ditemukan }\end{array}$ & 5) & $\begin{array}{l}\text { Ketika menemukan } \\
\text { barang, saya akan } \\
\text { menyerahkan kepada } \\
\text { pihak yang berwenang. }\end{array}$ & Valid \\
\hline
\end{tabular}




\begin{tabular}{|c|c|c|c|c|}
\hline \multirow[t]{2}{*}{ No } & \multirow[t]{2}{*}{ Indikator } & \multicolumn{2}{|r|}{ Item Kuisioner } & Hasil Uji \\
\hline & & 6) & $\begin{array}{l}\text { Saya tidak pernah } \\
\text { membawa barang yang } \\
\text { bukan milik saya. }\end{array}$ & Valid \\
\hline \multirow{2}{*}{\multicolumn{2}{|c|}{$\begin{array}{l}\text { 4. Membuat laporan } \\
\text { berdasarkan data atau } \\
\text { informasi apa adanya }\end{array}$}} & 7) & $\begin{array}{l}\text { Ketika membuat laporan, } \\
\text { saya mengungkapkan } \\
\text { berdasarkan data atau } \\
\text { informasi apa adanya. }\end{array}$ & Tidak Valid \\
\hline & & 8) & $\begin{array}{l}\text { Saya tidak pernah } \\
\text { memanipulasi laporan. }\end{array}$ & Valid \\
\hline \multirow{2}{*}{\multicolumn{2}{|c|}{$\begin{array}{l}\text { 5. Mengakui kesalahan atau } \\
\text { kekurangan yang dimiliki }\end{array}$}} & 9) & $\begin{array}{l}\text { Jika berbuat salah saya } \\
\text { akan mengakuinya. }\end{array}$ & Valid \\
\hline & & & $\begin{array}{l}\text { Saya sadar akan } \\
\text { kekurangan yang saya } \\
\text { miliki. }\end{array}$ & Valid \\
\hline
\end{tabular}

Diketahui variabel dalam penelitian menunjukkan hasil akhir Cronbach Alpha pendidikan karakter mandiri sebesar 0,894 > 0,7 beserta angka Cronbach Alpha pendidikan karakter jujur sebesar 0,798 > 0,7, dengan demikian dinyatakan reliabel. Uji asumsi klasik yang dilakukan terdapat 4 yakni uji normalitas, uji lineritas, uji multikolineritas, serta uji heteroskedastisitas. Uji normalitas menggunakan cara Kolmogrov Smirnov dengan hasil Asym.Sig senilai 0,636 >0,05, sehingga diambil ketetapan data terdistribusi normal. Dari hasil uji lineritas diketahui tingkat signifikansi Deviation from Linearity pertama senilai 0,219 > 0,05, yang artinya bahwa terdapat hubungan yang linear kepada variabel pendidikan karakter mandiri dengan variabel hasil belajar. Sedangkan untuk hasil nilai signifikansi Deviation from Linearity kedua sebesar 0,226 > 0,05 , yang berarti bahwa terdapat hubungan linear variabel pendidikan karakter jujur dengan variabel hasil belajar. Pada hasil uji multikolineritas memakai metode dengan nilai Tolerance serta VIF pada variabel pendidikan karakter mandiri dan pendidikan karakter jujur sama-sama memiliki nilai Tolerance sebesar 0,552 $>0.1$ dan nilai VIF sebesar $1.810<10$, sehingga tidak terjadi hubungan linier antar kedua variabel. Uji Heteroskedastisitas memakai cara uji Glejser, diperoleh nilai signifikansi uji glejser variabel pendidikan karakter mandiri sebesar $0.156>0,05$ dan pendidikan karakter jujur sebesar $0.157>0.05$. Sehingga, tak terjadi heteroskedastisitas maka varian residual sifatnya homokesdastisitas.

Berdasarkan uji koefisien determinasi terlihat nilai dari Adj R-Square 0.20 artinya variabel pendidikan karakter mandiri serta karakter jujur berhubungan terhadap hasil belajar sebesar 2\% sisanya 98\% dipengaruhi variabel lain diluar model. Pada uji hipotesis dilakukan guna pembuktian hipotesis penelitian. Berdasarkan angka uji t statistic pendidikan karakter mandiri ditemukan nilai thitung > ttabel sebesar $1.529>1.290$ dan memiliki nilai signifikansi $0.129>0.05$ maka ditarik kesimpulan pendidikan karakter mandiri tidak berpengaruh secara signifikan terhadap hasil belajar peserta didik. Dilihat dari hasil uji t statistic pendidikan karakter mandiri mendapat nilai thitung $>$ ttabel sebesar $1.995>1.667$ dan mempunyai angka signifikansi $0.049<0.05$ maka pendidikan karakter jujur berpengaruh signifikan terhadap hasil belajar peserta didik. Berdasarkan hasil uji F statistic mendapat nilai Fhitung > Ftabel sebesar $2.025>3.09$ demikian dinyatakan pendidikan karakter mandiri dan pendidikan karakter jujur secara simultan berkaitan signifikan terhadap hasil belajar. 
407 Pengaruh Pendidikan Karakter Mandiri dan Jujur Terhadap Hasil Belajar Ekonomi Koperasi Saat Pandemi Covid-19 - Putri Sugiyanti, Ni'matush Sholikhah

DOI: https://doi.org/10.31004/edukatif.v4i1.1755

\section{Pengaruh Pendidikan Karakter Mandiri Terhadap Hasil Belajar}

Hasil analisis penelitian memperlihatkan pendidikan karakter mandiri tidak berhubungan signifikan terhadap hasil belajar ekonomi pada materi ekonomi koperasi. Salah satu faktor yang mempengaruhi yaitu pada saat kondisi pembelajaran daring guru belum bisa memantau aktivitas/kegiatan siswa selama dirumah, sehingga penerapan pembelajaran pendidikan karakter mandiri belum bisa berjalan maksimal. Berdasarkan data yang didapatkan pada saat penelitian, selama pembelajaran tatap muka penerapan pendidikan karakter mandiri sudah berjalan dengan baik, berbeda dengan kondisi saat pembelajaran daring. Apabila dikaitkan dengan hasil belajar siswa saat ini cenderung cukup baik. (Poerwopoespito, 2010) Mandiri memiliki sebuah arti penting guna mendidik pribadi yang lebih tangguh. Mandiri merupakan tindakan mendapatkan bantuan dari seseorang atau orang lain guna mencapai kekuatan dan usaha sendiri. Bilamana sikap mandiri tidak dapat diterapkan sebagai landasan utama untuk masa depan maka sikap mandiri dalam individu akan sia-sia.

Menurut (Pramita, 2014) mandiri yakni cara atau perilaku ketika bertindak dan tidak mudah mengandalkan orang lain ketika menuntaskan tugas. Hasil penelitian ini selaras dengan penelitian (Maria, Rika, Rifma, 2021) yang menyatakan bahwa masih terdapat hambatan keefektifan pembelajaran serta pembinaan pendidikan karakter di masa pandemi Covid-19 diantaranya yaitu orang tua yang belum bisa memahami pola implementasi pendidikan karakter anak. Pendidik juga mengalami hambatan ketika menerapkan penyelenggaraan pendidikan karakter di sekolah. Pendidikan karakter dapat berjalan maksimal apabila didukung pihak keluarga, karena orang tua merupakan faktor penunjang keberhasilan pendidikan karakter. Hal tersebut berbanding terbalik dengan penelitian (Pramita, 2014), mengungkapkan bahwa penerapan pendidikan karakter mandiri di sekolah dapat meningkatkan hasil belajar peserta didik. Menurut (Asrori, 2014) faktor-faktor yang mempengaruhi kemandirian yakni keturunan dari orang tua, pola asuh orang tua,sistem pendidikan disekolah,dan sistem kehidupan di masyarakat. Ciri-ciri kemandirian menurut (Gea, 2012) yaitu percaya diri, mampu bekerja individu, memahami keahian dan keterampilan, dapat memanajemen waktu, serta bertanggungjawab.

Dengan demikian, dapat diketahui bahwa pembentukan karakter mandiri di sekolah masih perlu untuk ditingkatkan kembali. Salah satu caranya yaitu dengan terus menelaah faktor-faktor yang menjadi kendala pembelajaran daring pada kebiasaan karakter mandiri peserta didik dengan mencari solusi agar semua permasalahan dapat teratasi dengan baik dan peserta didik dapat terbiasa mandiri untuk mengerjakan tugas.

\section{Pengaruh Pendidikan Karakter Jujur Terhadap Hasil Belajar}

Hasil analisis penelitian mengungkapkan pendidikan karakter jujur berpengaruh signifikan serta positif pada hasil belajar materi ekonomi koperasi. Peserta didik yang memiliki karakter jujur akan terbiasa untuk mengerjakan sesuatu dengan baik sehingga dari kebiasaan tersebut dapat meningkatkan hasil belajarnya (Cicyn Riantoni, 2020). Kejujuran peserta didik tersebut dapat diidentifikasi dengan ucapan, perlakuan maupun aktivitas dalam kehidupan sehari-hari disekolah, dirumah atau dilingkungan masyarakat. Ucapan peserta didik yang jujur dapat dipercaya karena perkataanya sesuai dengan fakta yang terjadi. Tindakan dan kegiatan peserta didik yang jujur harus dilakukan berlandaskan tata tertib dan tidak melakukan penyelewengan. Kejujuran siswa juga terlihat saat menyelesaikan tugas yang diberi guru dan ketika ujian.

Pernyataan tersebut sesuai dengan penelitian (Lase \& Nirwana, 2020) mengungkapkan bahwa model pembelajaran karakter jujur dapat mengubah kepribadian siswa dari kurang baik menjadi sangat baik dan dengan adanya penerapan tersebut dapat memperbaiki hasil belajarnya. Hal tersebut juga sesuai dengan penelitian (Cicyn Riantoni, 2020) bahwa ada keterkaitan antara karakter jujur siswa dengan hasil belajarnya dimana apabila siswa memiliki nilai karakter yang rendah, maka hasil belajarnya juga relatif rendah. Hasil penelitian tersebut juga selaras dengan penelitian (Rochmawati, 2018), bahwa pembiasaan karakter jujur untuk anak sangat perlu diterapkan agar dapat membuat masa depan generasi penerus bangsa yang jujur dan tidak berperilaku salah arah dalam kehidupannya sendiri maupun dalam kehidupan berbangsa dan bernegara. 
408 Pengaruh Pendidikan Karakter Mandiri dan Jujur Terhadap Hasil Belajar Ekonomi Koperasi Saat Pandemi Covid-19 - Putri Sugiyanti, Ni'matush Sholikhah

DOI: https://doi.org/10.31004/edukatif.v4i1.1755

Oleh karena itu, peran guru dan orangtua dalam menanamkan karakter jujur ini sangat penting. Sedangkan dalam Rita \& Izzaty (2008) jujur berarti lurus hati, tidak curang dalam melakukan suatu tindakan atau tugas yangtelah diberikan, tidak berbohong dengan orang dilingkungan sekitar atau kepada orang tua ,tulus dan ikhlas dalam mengerjakan tugas yang telah diberikan, sedangkan kejujuran ialah sikap berfikir jujur, berkata jujur,dan bersikap jujur. Artinya sesuatu dilakukan tidak berbohong, tidak curang, dan ikhlas.

Menurut Dharma (2012) ciri-ciri orang jujur adalah bertekad atau mengambil keputusan melakukan sesuatu tekadnya yakni kebenaran, jadi saat peserta didik sedang mengambil keputusan diharapkan keputusan yang sedang diambil adalah keputusan yang benar. Jika berkata tidak berbohong atau benar apa adanya, peserta didik dapat dipercaya yaitu dengan ucapannya, peserta didik dapat dipercaya ketika berbica sejujurnya tidak berbohong kepada siapapun. Adanya persamaan dalam perkataan, ucapan dan tindakan peserta didik harus sama, apa yang sedang diucapkan oleh peserta didik termasuk apa yang telah terjadi.

Dengan demikian, apabila peserta didik mampu menerapkan karakter jujur yang baik saat pembelajaran daring masa pandemi Covid-19 sehingga meningkatkan hasil belajarnya. Salah satu caranya yaitu dengan tetap melaksanakan pearturan yang ada sesuai yang diajarkan di sekolah agar peserta didik juga menerapkan perilaku jujur di kehidupan sehari-hari.

\section{Pengaruh Pendidikan Karakter Mandiri dan Karakter Jujur Terhadap Hasil Belajar}

Berdasarkan dua hasil penelitian variabel sebelumnya dibahas secara parsial bersamaan pendidikan karakter mandiri dan karakter jujur berhubungan signifikan terhadap hasil belajar ekonomi koperasi. Hasil penelitian ini sesuai dengan studi (Jumiati, 2021) bahwa selama pembelajaran daring di tengah pandemi Covid-19 pendidikan karakter mandiri dan jujur merupakan faktor penting yang harus diterapkan pada siswa agar menjadi lebih baik. Hal tersebut juga selaras dengan penelitian (Irjanti \& Setiawati, 2018) yang menyatakan bahwa nilai karakter mempunyai pengaruh positif terhadap prestasi belajar peserta didik.

Siswa yang tidak mempunyai karakter mandiri dan jujur cenderung melanggar tata tertib yang berlaku. Siswa yang tidak mandiri selalu bergantung kepada temannya dan tidak ingin berusaha untuk dapat menyelesaikannya sendiri. Selain itu apabila siswa terbiasa untuk berbuat tidak jujur maka akan cenderung suka berbohong dan tidak menuruti pelajaran dengan tertib dikelas. Kegiatan tersebut berdampak buruk terhadap hasil belajar peserta didik Siswa yang tidak mandiri dan jujur menghadapi hambatan ketika menyelesaikan tangunggan atau ujian yang dibagikan guru sehingga dapat mempengaruhi hasil belajar turun. (Marzuki, 2015).

Dengan demikian, ditarik disimpulkan bahwa hasil belajar merupakan indikator tercapainya pembelajaran adalah melihat hasil belajar yang telah diraih peserta didik. Salah satu indikatornya yaitu dapat dilihat dari penerapan pendidikan karakter mandiri dan pendidikan karakter jujur yang diterapkan, apabila sudah berjalan dengan baik maka mempengaruhi hasil belajar peserta didik pada sekolah.

\section{KESIMPULAN}

Berdasarkan hasil studi dan pemaparan yang telah dijabarkan, ditarik kesimpulan : (1) secara parsial tidak ada pengaruh antar variabel pendidikan karakter mandiri terhadap hasil belajar ekonomi (2) secara parsial terdapat hubungan signifikan antar variabel pendidikan karakter jujur terhadap hasil belajar ekonomi (3) secara simultan ada hubungan signifikan antar pendidikan karakter mandiri dan karakter jujur pada hasil belajar ekonomi. Salah satu faktor yang mempengaruhi yaitu pada saat kondisi pembelajaran daring guru belum bisa memantau aktivitas/kegiatan siswa selama dirumah, sehingga penerapan pembelajaran pendidikan karakter mandiri belum bisa berjalan maksimal. Dengan demikian, ditarik kesimpulan yakni hasil belajar ialah indikator tercapainya pembelajaran yakni dengan melihat hasil belajar yang telah dicapai oleh peserta didik. Salah satu indikatornya yaitu dapat dilihat dari penerapan pendidikan karakter mandiri dan pendidikan 
409 Pengaruh Pendidikan Karakter Mandiri dan Jujur Terhadap Hasil Belajar Ekonomi Koperasi Saat Pandemi Covid-19 - Putri Sugiyanti, Ni'matush Sholikhah

DOI: https://doi.org/10.31004/edukatif.v4i1.1755

karakter jujur yang diterapkan, apabila sudah berjalan dengan baik maka dapat memperngaruhi hasil belajar peserta didik saat disekolah.

\section{DAFTAR PUSTAKA}

Asrori, A. (2014). Psikologi Remaja Perkembangan Peserta Didik. Hal 118.

Cicyn Riantoni, A. N. (2020). Analisis Tingkat Hubungan Karakter Jujur Siswa Terhadap Hasil Belajar Ipa Terpadu. 7(1), 127-142.

Dharma, K. (2012). Pendidikan Karakter: Kajian Teori Dan Praktik Di Sekolah (P. Hal 17). Pt Remaja Rosdakarya.

Gea, A. (2012). Relasi Dengan Diri Sendiri. Modul Chaaracter Building. Pt Gramedia.

Irjanti, R., \& Setiawati, A. (2018). Pengaruh Nilai-Nilai Karakter Terhadap Prestasi Belajar Di Sdit Salman Al Farisi. Jurnal Pendidikan Karakter, 40-50.

Jannah, N. U. (2018). Pengaruh Pembelajaran Berbasis Pendidikan Karakter Terhadap Hasil Belajar Siswa. Hal 54.

Jumiati, T. \& M. A. (2021). Pembelajaran Nilai-Nilai Karakter: Tantangan Penanaman Nilai Karakter Melalui Pembelajaran. 6(1), 28-39.

Lase, F., \& Nirwana, H. (2020). The Differences Of Honest Characters Of Students Before And After Learning With A Model Of Learning Of Intelligent Character. 3(1), 41-48.

Maria, Rika, Rifma, S. (2021). Edukatif: Jurnal Ilmu Pendidikan Perkembangan Pendidikan Indonesia Di Masa Pandemi Covid-19 Abstrak. 3(2), 456-462.

Marzuki. (2015). Pengintegrasian Pendidikan Karakter Dalam Pembelajaran Disekolah. Jurnal Pendidikan Karakter, 33-44.

Poerwopoespito, U. (2010). Menggugah Mentalitas Profesional Dan Pengusaha Indonesia. Grasindo.

Pramita, C. F. P. \& M. (2014). Meningkatkan Karakter Mandiri Dan Hasil Belajar Matematika Siswa Melalui Model Pembelajaran Kooperatif Tipe Think Pair Share (Tps) Di Kelas Viii-C Smpn 13 Banjarmasin. 01(2), 17-32.

Pratiwi, N. I. (2017). Penggunaan Media Video Call Dalam Teknologi Komunikasi. Jurnal Ilmiah Dinamika Sosial, 1(2), 202-224.

Priyono. (2008). Metode Penelitian Kuantitatif.

Purwanto, N. (2012). Psikologi Pendidikan. Remaja Rosda Karya.

Puspita, I. (2012). Pendidikan Karakter Jujur (P. Halaman 3). Cahaya Bangsa Mijen.

Rita, \& Izzaty. (2008). Perkembangan Peserta Didik. Uny Press.

Rochmawati, N. (2018). Peran Guru Dan Orang Tua Membentuk Karakter Jujur Pada Anak. Jurnal Al-Fikri: Jurnal Studi Dan Penelitian Pendidikan Islam, 1(2), 1-12.

Rostrieningsih, \& Maisaroh. (2010). Peningkatan Hasil Belajar Siswa Dengan Menggunakan Metode Pembelajaran Active Learning Tipe Quiz Team Pada Mata Pelajaran Keterampilan Dasar Komunikasi Di Smk Negeri 1 Bogor - Maisaroh Dan Rostrieningsih. Jurnal Ekonomi \& Pendidikan, Volume 8(No 2), 157-172.

Samani, M., \& Hariyanto. (2011). Konsep Dan Model Pendidikan Karakter (P. Hlm.44). Pt Remaja Rosdakarya.

Sudjana. (2010). Cara Belajar Siswa Aktif Dalam Proses Belajar Mengajar. Sinar Baru Algensindo. 
410 Pengaruh Pendidikan Karakter Mandiri dan Jujur Terhadap Hasil Belajar Ekonomi Koperasi Saat Pandemi Covid-19 - Putri Sugiyanti, Ni'matush Sholikhah

DOI: https://doi.org/10.31004/edukatif.v4i1.1755

Sugiyono. (2012). Metode Penelitian Pendidikan Pendekatan Kuantitatif, Kualitatif, Dan R\&D. Alfabheta.

Sugiyono. (2019). Metode Penelitian Kuantitatif.

Wahyuliono, T. (2013). Pengaruh Pendidikan Karakter Terhadap Hasil Belajar Siswa Kelas Xi Pada Mata Pelajaran Produktif Teknik. 1, 40-44.

Waliyanti. (2014). Pengembangan Karakter Kemandirian. Jurnal Publikasi.

Wibawanto. (2017). Desain Dan Pemograman Multimedia Pembelajaran Interaktif. Cerdas Ulet Kreatif.

Yaumi, M. (2014). Pendidikan Karakter : Landasan, Pilar \& Implementasi. Hlm 120.

Zubaedi. (2011). Design Pendidikan Karakter. In Pendidikan Islam (Vol. 7). Prenada Media Grup. 